Worldly Shakespeare 
For Dominique Goy-Blanquet

Brave des Braves 


\section{Worldly Shakespeare}

The Theatre of Our Good Will

Richard Wilson 
(c) Richard Wilson, 2016

The Tun - Holyrood Road, I2(2f) Jackson's Entry, Edinburgh EH8 8PJ

www.euppublishing.com

Typeset in Io/r 2pt Goudy Old Style by Servis Filmsetting Ltd, Stockport, Cheshire, and printed and bound in Great Britain by CPI Group (UK) Ltd, Croydon, CRo 4 YY

A CIP record for this book is available from the British Library

ISBN 978 I 4744 I 1325 (hardback)

ISBN 978 I 4744 I 1332 (webready PDF)

ISBN 978 I 4744 I I 349 (paperback)

ISBN 978 I 4744 I 1356 (epub)

The right of Richard Wilson to be identified as the author of this work has been asserted in accordance with the Copyright, Designs and Patents Act 1988, and the Copyright and Related Rights Regulations 2003 (SI No. 2498). 